\title{
Penanganan Ayam Broiler Sebelum dan Sesudah Pemotongan: Studi Pengolahan Daging Broiler di Kota Mataram dan Sekitarnya
}

\author{
Handling of Broiler Before and After Slaughter: Study of Broiler Meat \\ Processing in Mataram City and its Surroundings
}

\author{
M. H. Tamzil*, I. N. S. Jaya, M. Ichsan, Asnawi, N. K. D. Haryani, \& P. Nugroho \\ Fakultas Peternakan Universitas Mataram \\ Jalan Majapahit No. 62 Mataram Lombok, Nusa Tenggara Barat, Indonesia. 83125. \\ *Email korespondensi: emhatamsil@yahoo.com
}

\begin{abstract}
- Diterima: 22 Desember 2020 • Direvisi: 29 Januari 2021 • Disetujui: 15 Februari 2021
ABSTRAK. Penelitian bertujuan untuk mengetahui pola penanganan dan pemotongan ayam broiler di kota Mataram dan sekitarnya. Penelitian dilakukan dengan metode surve dan wawancara mendalam serta melakukan pengamatan langsung ke tempat usaha. Sebagai sumber data adalah peternak, pengepul, dan pemotong yang tersebar di kota Mataram dan sekitarnya. Penentuan sampel menggunakan metode Nonprobability Sampling, dengan penentuan peternak dan pengepul menggunakan metode Sampling Insidental, sedangkan penentuan sampel RPA menggunakan metode Snowball Sampling. Peubah yang diamati adalah: a). Karakteristik responden, b). Penanganan di ahir masa pemeliharaan, c). Pola penangkapan dan pemindahan ke boks dan kendaraan angkut, d). Waktu pengangkutan, e) Lama dan jarak pengangkutan, f). Penanganan ayam saat pemindahan dari kendaraan angkut ke tempat karantina, g). Perlakuan pengistirahatan, h). Pelaksanaan penyembelihan. Data yang diperoleh dianalisa secara deskriptif. Hasil penelitian mendapatkan bahwa proses penangkapan dan pengangkutan ayam broiler dari peternak ke tempat pemotongan ayam (TPA) tidak dijumpai adanya pelanggaran Animal welfare, namun ada indikasi pelanggaran di proses pencelupan di air panas setelah penyembelihan. Proses penyembelihan masih belum mengikuti prosudur baku yang ditetapkan oleh Direktorat Kesmavet dan Pasca Panen, dan BSNI, namun sudah mengikuti prosudur baku yang ditetapkan oleh Majelis Ulama Indonesia, sehingga produk yang dihasilkan tergolong daging halal.
\end{abstract}

Kata kunci: Proses pengangkutan, penangkapan, penyembelihan, prosesing daging, halal

ABSTRACT. This study aims to determine the pattern of handling and slaughtering broiler chickens in the city of Mataram and its surroundings. The study was conducted using survey methods and in-depth interviews and direct observations of the place of business. Data were collected from farmesr, distributors, and butchers in the city of Mataram and its surroundings. The samples were determined using the Nonprobability Sampling method. Farmer and distributor were determined using the Incidental Sampling method, while the RPA samples were determined using the Snowball Sampling method. The observed variables were: a). Characteristics of respondents, b). Handling at the end of the rearing period, c). The pattern of catching and transferring of the chickens to boxes and transport vehicles, d). Time of transportation, e) Length and distance of transportation, f). Handling of chickens when moved from transport vehicles to quarantine facilities, g). Rest treatment, h). Slaughter implementation. The data obtained were analyzed descriptively. The results showed that the process of catching and transporting broiler chickens from farmer to chicken slaughterhouses did not violate animal wefare, but there were violation indications when the chickens were put in hot water after slaughtering. The slaughtering process still does not follow the standard procedure set by the Directorate of Veterinary Public Health and Post-Harvest, and BSNI, but has followed the standard procedure set by the Indonesian Ulama Council, so the final product is classified as halal meat.

Key words: The process of transporting, catching, slaughtering, meat processing, halal

\section{PENDAHULUAN}

Salah satu aspek yang mempunyai kontribusi besar pada kualitas daging broiler adalah aspek penanganan pasca panen. Aspekaspek tersebut meliputi aspek pemberian obatobatan sebelum pengangkutan, perlakuan pengepakan (penangkapan dan kepadatan ternak dalam box), pengangkutan (waktu dan lama pengangkutan), dan pemberian waktu istirahat sebelum pemotongan (Zulkifli, et al., 2009, Zhang et al. 2009). Faktor lain yang juga perlu diperhatikan adalah tingkah laku ayam yang cepat nervous dan membutuhkan perlakuan khusus selama masa produksi dan pasca produksi; bila tidak akan memunculkan 
rasa tidak aman dan mengganggu homeostasis dalam tubuh (Ewing et al, 1999: Morberg, 2000). Faktor pengangkutan merupakan tahapan yang pendek, namun aktivitas ini sering menyebabkan kerugian yang cukup besar, karena selama pengangkutan ternak menderita stres (Zhang et al., 2009; Doktor and Poltowie, 2009; Tamzil et al. 2019). Kerugian dapat bersumber dari tingginya angka kematian selama pengangkutan serta menurunnya kualitas daging karena pengaruh stres (Barbut et al., 2008; Zhang et al., 2009; Doktor and Poltowiez, 2009; Jayaprakash et al., 2016).

Faktor pemicu munculnya stres selama pengangkutan antara lain adalah ketidaksediaan pakan, penangkapan, bongkar muat, penanganan saat pemindahan dari kandang ke boks, kepadatan ternak dalam boks, gangguan sosial, pembatasan gerak, radiasi panas, tiupan angin, kebisingan, dan getaran (Zulkifli et al., 2009, Tamzil, 2016). Dampak pengangkutan menjadi semakin parah karena kondisi biologis ayam yang tidak mempunyai kelenjar keringat, dan hampir seluruh bagian tubuhnya ditutupi bulu (Lin et al. 2005; AlFataftah \& Abu-Dieyeh 2007; Al-Ghamdi 2008; Al-Aqil \& Zulkifli 2009; Zulkifli et al. 2009; Ajakaiye et al. 2010, Tamzil. 2014), sehingga selama pengangkutan broiler menderita stres berat. Pada tahap selanjutnya di dalam tubuh terjadi proses pemecahan glikogen otot yang berlebihan dan penumpukan asam laktat, dan setelah pemotongan akan menghasilkan daging dengan $\mathrm{pH}$ rendah, warna pucat, lembek dan berair (PSE=pale, soft exudatif) (Barbut, et al., 2008; Ali et al. 2008, Zhang et al. 2009; Lengkey et al. 2013).

Langkah antisipasif untuk mengurangi efek negatif stres pengangkutan adalah pemberian waktu istirahat yang cukup setelah sampai di tempat pemotongan (Tamzil et al. 2019), namun bila tidak akan tetap menghasilkan daging PSE (pale, soft exudatif) (Barbut, et al., 2008; Ali et al. 2008, Zhang et al. 2009; Lengkey et al. 2013). Faktor lain yang tidak kalah pentingnya dalah proses pemotongan dan pengolahan sampai menjadi daging. Untuk mendapatkan daging yang asli, sehat, utuh dan halan (ASUH), sudah diatur oleh Direktorat Jendral Veteriner dan Pasca panen (2010), Badan Standarisasi Nasional (BSN) (1999), dan
Fatwa Majelis Ulama Indonesia (MUI) (2009). Permasalahannya adalah standar baku yang sudah ditetapkan belum diketahui aplikasinya oleh pelaku usaha pemotongan ayam (TPA). Informasi ini sangat diperlukan sebagai dasar untuk melakukan pembinaan oleh berbagai pihak untuk menghasilkan daging yang ASUH.

\section{METODE PENELITIAN}

Penelitian ini merupakan penelitian survey dengan melakukan wawancara mendalam (indepth interview) dan pengamatan langsung pada lokasi usaha, dengan sumber adalah peternak ayam broiler, pengepul, dan pemotong. Penelitian dilakukan di kota Mataram dan sekitarnya dengan mewawancarai stake holders yang berhubungan dengan usaha pemotongan ayam broiler.

Penentuan sampel dalam penelitian ini menggunakan metode Nonprobability Sampling, dengan rincian penentuan responden peternak dan pengepul menggunakan metode Sampling Insidental (kebetulan), sedangkan penentuan sampel pengusaha pemotong menggunakan pendekatan metode Snowball Sampling.

Data yang dikumpulkan adalah 1). Karakteristik responden (umur, pendidikan, dan pengalaman). 2). Penanganan broiler sebelum pengangkutan. Data ini diperoleh dengan cara melakukan wawancara mendalam dengan peternak dan pengamatan langsung di lokasi peternakan. 3). Penanganan selama pengangkutan (pola penangkapan dan pemindahan ke boks dan kendaraan angkut, waktu pengangkutan, dan penanganan ayam saat pemindahan dari kendaraan angkut ke tempat penampungan sementara). Data ini diperoleh dengan cara melakukan wawancara mendalam dengan pengepul dan pengamatan langsung saat proses berlangsung. 4). Perlakuan setelah pengangkutan (pengistirahatan, dan proses penyembelihan dan pengolahan daging). Data ini diperoleh dengan melakukan wawancara mendalam dengan pengusaha pemotong dan pengamatan langsung di tempat pemotongan ayam. Data yang diperoleh di lapangan dianalisis secara deskriptif. 


\section{HASIL DAN PEMBAHASAN}

Peternak ayam broiler yang menjadi penyedia ayam broiler di kota Mataram, pengusaha pengepul, dan pengusaha pemotongan ayam broiler di kota Mataram didominasi oleh individu dengan kriteria sebagian besar berumur pada kisaran umur produktif, berpendidikan sarjana, dan dengan pengalaman menggeluti usaha cukup lama (Tabel 1). Pelaku bisnis dengan kriteria seperti ini memberikan potensi besar untuk memajukan usaha. Individu dengan tingkat pendidikan tinggi dan usia produktif dapat beradaptasi dengan cepat dengan tantangan baru serta mudah memahami dan menggunakan teknologi. Namun lain halnya dengan pekerja usia non produktif, berpendidikan rendah dan dengan pengalaman yang kurang, akan berdampak pada kemampuan fisik dan berfikir serta sulit untuk dapat beradaptasi dengan teknologi (Trivedi dan Bhargava, 2010).
Data pada Tabel 1 juga menunjukkan usaha pemotongan ayam di kota Mataram dan sekitarnya dilakukan oleh individu yang beragama Islam. Kondisi ini sangat menguntungkan masyarakat kota Mataram dan sekitarnya yang mayoritas beragama Islam. Persyaratan daging boleh dikonsumsi oleh umat Islam antara lain adalah harus mengikuti Fatwa Majelis Ulama Indonesia Nomor 12 tahun 2009 tentang standar penyembelihan halal (MUI, 2009). Proses penyembelihan dikatakan penyembelihan halal bila: 1) dilaksanakan dengan niat menyembelih dan menyebut asma Allah, yaitu Bismillahirrahmanirrahim; 2) Penyembelihan dilakukan dengan mengalirkan darah melalui pemotongan saluran makanan (esophagus), saluran pernafasan (trachea), dan dua pembuluh darah (vena jugularis dan arteri carotids); 3) Penyembelihan sampai ayam mati dengan satu sembelihan dengan cara yang cepat (MUI, 2009).

Tabel 1. Karakteristik responden (umur, pendidikan, agama, pengalaman)

\begin{tabular}{|c|c|c|c|}
\hline \multirow{2}{*}{ Karakteristik } & \multicolumn{3}{|c|}{ Bidang usaha } \\
\hline & Peternak (\%) & Pengepul (\%) & Pemotong $(\%)$ \\
\hline \multicolumn{4}{|l|}{ 1. Umur (tahun) } \\
\hline - $<20$ & 0 & 0 & 0 \\
\hline - $20-29$ & 14,28 & 0 & 0 \\
\hline - $30-39$ & 41,86 & 100 & 5 \\
\hline - $40-49$ & 28,57 & 0 & 30 \\
\hline - $\geq 50$ & 14,28 & 0 & 65 \\
\hline Jumlah & 100 & 100 & 100 \\
\hline \multicolumn{4}{|l|}{ 2. Tingkat Pendidikan } \\
\hline - Sekolah Dasar & 0,00 & 0,00 & 0,00 \\
\hline - Sekolah Menengah Tingkat Pertama & 0,00 & 0,00 & 0,00 \\
\hline - Sekolah Menengah Tingat Atas & 14,30 & 57,14 & 15 \\
\hline - Sarjana/Diploma & 85,70 & 42,86 & 85 \\
\hline Jumlah & 100 & 100 & 100 \\
\hline \multicolumn{4}{|l|}{ 3. Pengalaman (tahun) } \\
\hline - $<10$ & 14,30 & 20 & 50 \\
\hline - $10-20$ & 85,70 & 60 & 40 \\
\hline - $\geq 20$ & 0,00 & 20 & 10 \\
\hline Jumlah & 100 & 100 & 100 \\
\hline \multicolumn{4}{|l|}{ 4. Agama } \\
\hline - Islam & 100 & 100 & 100 \\
\hline - Hindu & 0,00 & 0,00 & 0,00 \\
\hline - Kresten & 0,00 & 0,00 & 0,00 \\
\hline - Katolik & 0,00 & 0,00 & 0,00 \\
\hline - Konghucu & 0,00 & 0,00 & 0,00 \\
\hline Jumlah & 100 & 100 & 100 \\
\hline
\end{tabular}


Ayam yang disembelih di Tempat Pemotongan Ayam (TPA) di kota Mataram berasal dari luar kota Mataram yaitu dari daerah Lombok Barat (95\%) dan Lombok Tengah (5\%). Fenomena tidak adanya ayam yang berasal dari daerah kota Mataram disebabkan karena kota Mataram merupakan pusat pemerintahan, pusat pendidikan, pusat perdagangan, sehingga sebagian besar wilayah kota Mataram dipenuhi oleh bangunan untuk aktivitas perkantoran, pusat pendidikan, pusat perdagangan dan pemukiman, dan sangat sedikit yang dipergunakan sebagai sentra pertanian termasuk peternakan ayam broiler.

Hasil wawancara mendalam dengan peternak didapat informasi tidak ada petugas yang datang mengontrol kesehatan ayam di setiap kali penjualan ayam, namun diakui bahwa ayam yang akan dipasarkan harus sehat dan bebas dari pemberian antibiotik. Hal ini berarti peternak ayam broiler di Lombok Barat dan Lombok Tengah (sumber ayam di kota Mataram) paham mekanisme pemberian antibiotik dan bahaya residu antibiotik dalam daging broiler untuk kesehatan konsumen (Etikaningrum dan Iwantoro, 2017). Diperoleh juga informasi bahwa peternak tidak melakukan penjualan terhadap ayam yang kurang sehat atau sakit, dan ayam yang mempunyai cacat tubuh. Munculnya kesadaran ini erat hubungannnya dengan tingginya tingkat pendidikan responden dan pengalaman menggeluti usaha yang cukup panjang. Adanya pengetahuan dan kesadaran yang cukup tinggi ini mungkin yang menyebabkan cemaran antibiotik dalam daging broiler pada kurun waktu 2011-2016 cenderung menurun, seperti yang dilaporkan Consalesius et al. (2014) dan Yulianti et al. (2016).

Tabel 2. Jarak antara tempat pemeliharaan dengan TPA

\begin{tabular}{cc}
\hline Jarak $(\mathrm{Km})$ & Jumlah $(\%)$ \\
\hline$<10$ & 45 \\
$10-20$ & 35 \\
$21-30$ & 20 \\
$>30$ & 0 \\
\hline Jumlah & 100 \\
\hline
\end{tabular}

Tabel 3. Waktu pengangkutan ayam dari peternak ke TPA

\begin{tabular}{cc}
\hline Waktu & Jumlah (\%) \\
\hline Pagi & 0 \\
Siang & 0 \\
Sore & 80 \\
Malam & 20 \\
\hline Jumlah & 100 \\
\hline
\end{tabular}

Penangkapan ayam dan pemindahan ayam dari kandang ke kendaraan dilakukan dengan terlebih dahulu mengangkat tempat pakan (ditinggikan), kemudian dibuat sekat untuk memudahkan penangkapan. Penangkapan dilakukan dengan cara mengambil kaki terlebih dahulu dan selanjutnya kaki ayam diikat menggunakan tali dan ditimbang untuk mengetahui bobot badan. Kepadatan ayam dalam boks biasanya disesuaikan dengan bobot badan dan jumlah orderan masing-masing TPA. Ayam-ayam tersebut diangkut ke TPA menggunakan kendaraan terbuka dengan jarak tempuh seperti tertera pada Tabel 2 dan lama pengangkutan seperti tertera pada Tabel 3. Boks-boks yang telah terisi ayam ditempatkan bersusun di atas bak dan selanjutnya diantar ke lokasi TPA. Terlihat jarak antara tempat pemeliharaan (asal ayam) dengan TPA relatif dekat. Sebanyak 80 persen ayam yang dipotong di kota Mataram berasal dari daerah dengan jarak kurang dari 10 sampai dengan $20 \mathrm{~km}$. Hanya 20\% yang berasal dari daerah dengan jarak lebih dari 20 km. Jarak dan lama pengangkutan dari lokasi pemeliharaan ke TPA berpengaruh pada kondisi fisiologis ternak dan selanjutnya berpengaruh pada kualitas daging yang 
dihasilkan (Tamzil et al. 2016, Tamzil et al. 2018, Tamzil et al. 2019).

Data waktu pengiriman dan jarak antara tempat pemeliharaan dan TPA disajikan pada Tabel 2. Terlihat waktu pengangkutan ayam dari tempat pemeliharaan ke tempat pemotongan umumnya dilakukan pada waktu sore dan malam hari, berikutnya beberapa jam di kandang karantina. Praktek pengangkutan seperti ini membuktikan pelaku bisnis pengangkutan (pengepul) ayam di kota Mataram, paham dengan fisiologi unggas. Pengalaman panjang menekuni usaha pengangkutan ayam memberikan pelajaran dan pengetahuan praktis waktu pengangkutan ayam broiler yang paling baik. Pengangkutan pada siang hari berdampak pada kenyamanan ayam, yaitu ayam menderita stres karena paparan sinar matahari langsung, suasana sosial yang berdesak-desakan, serta adanya tiupan angin yang kencang. Dampak selanjutnya adalah tingginya angka kematian, serta menurunkan kualitas daging yang dihasilkan (Tamzil et al. 2018). Tingginya pemahaman ilmu praktis pelaku bisnis pengangkutan ayam broiler (pengepul) juga dapat dilihat dari perlakuan yang diberikan kepada ayam sebelum pengangkutan. Untuk mengurangi pengaruh stres pengangkutan yang berlebihan, sebelum pengangkutan diberi perlakuan penyiraman menggunakan air. Tujuannya adalah untuk membantu menurunkan suhu tubuh ayam yang muncul karena pengaruh stres pengangkutan (Tamzil et al. 2018). Selama proses penangkapan, hanya pada proses pengisian ayam ke dalam boks yang terindikasi melanggar Animal Welfare, yaitu boks diisi sesuai dengan jumlah orderan TPA. Sistem pengisian boks seperti ini dapat mendatangkan efek yang kurang baik terhadap kesejahteraan ayam (Animal Welfare). Pada sistem ini memungkinkan pengisian boks dengan kapasitas melebihi daya tampung, sehingga muncul kasus cidera patah tulang, memar dan muncul stres pengangkutan. Stres pengangkutan umumnya muncul sebagai akibat dari keterbatasan ruangan dalam boks, tiupan angin, dan sengatan sinar matahari langsung (Tamzil et al. 2016, Tamzil et al. 2018, Tamzil et al. 2019).
Hasil pengamatan di TPA diperoleh informasi rata-rata pengusaha pemotongaan ayam broiler di kota Mataram dan sekitarnya masih menggunakan manajemen dan fasilitas tradisional. Pemotongan dilakukan di sekitar pekarangan dengan fasilitas seadanya. Tidak tersedia fasilitas seperti yang disarankan oleh Direktorat Kesmavet dan Pasca Panen Dirjen Peternakan dan Kesehatan Hewan (2010) dan BSN (1999) yang dapat dimanfaatkan untuk mencegah kontaminasi karena kontak antara daging ayam dengan lantai. Semua TPA di kota Mataram dan sekitarnya melakukan proses pemotongan pada malam hari. Aktivitas dilakukan dalam satu ruangan. Tidak tersedia ruangan atau area untuk yang kotor dan yang bersih. Dengan demikian dapat dikatakan TPA yang ada di kota Mataram masih belum memenuhi standar yang ditetapkan pemerintah (Direktorat Kesmavet dan Pasca Panen. 2010) maupun Standar Nasional Indonesia SNI- 016160-1999 (Badan Standardisasi Nasional, 1999). Keterbatasan fasilitas ini berdampak pada sulitnya menghindari pencemaran, sehingga daging menjadi kurang higienis, dan kurang memenuhi persyaratan sebagai daging yang ASUH.

Pemotongan ayam di semua TPA di kota Mataram menggunakan ritual Islam. Juru Potong adalah individu yang taat beragama, sudah akil baliq, memotong satu kali dengan cepat, menggunakan pisau tajam, serta menyebut nama Allah (membaca Basmallah/Bismillahirrahmanirrahim) sebelum penyembelihan. Penyembelihan dilakukan pada daerah leher dengan memutus saluran pernafasan, dan dua pembuluh darah secara cepat, serta dipastikan ayam mati karena penyembelihan (MUI, 2009). Meskipun demikian terdapat prosedur yang kurang tepat saat memasukkan ayam yang sudah disembelih ke dalam air panas. Sama sekali tidak diperhatikan apakah ayam yang sudah disembelih sudah mati atau tidak, langsung dimasukkan ke dalam air panas. Praktik seperti ini menimbulkan pertanyaan, apakah ayam mati karena proses penyembelihan atau mati karena proses pencelupan dalam air panas. Meskipun demikian praktik seperti ini sudah memenuhi prosedur peyembelihan yang ditetapkan MUI (2009), namun proses 
pencelupan ke dalam air panas dipandang sebagai tindakan penyiksaan dan melanggar Animal Welfare. Nabi Besar Muhammad SAW menyatakan dalam hadis shoheh Muslim no. 19955: Sesungguhnya Allah telah memerintahkan untuk berbuat ihsan (kebaikan) pada tiap-tiap urusan, maka apabila kamu membunuh maka perbaikilah cara membunuhnya, dan apabila kamu menyembelih maka perbaikilah cara sembelihannya dan tajamkanlah pisaumu dan entengkanlah binatang sembelihanmu (AlMundziri, 2009).

Kasus lain yang ditemukan di lapangan adalah kasus pelapalan kalimat Bismillahirrahmanirrahim. Ditemukan pada sebuah TPA yang menyembelih tidak melapalkan kalimat Basmalllah. Permasalahan ini terdapat dua pendapat. Pendapat pertama (Mazhab Hanafi) mengatakan bahwa wajib hukumnya melapazkan bacaan Basmallah, bila tidak hasil sembelihannnya tergolong bangkai. Mazhab Syafi`i mengatakan melapazkan Basmalah hukumnya Sunnah, bila ditinggalkan hukumnya Makruh. Bila kita melihat kondisi umat Islam di pulau Lombok yang mayoritas menganut Mazhab Syafi i maka hasil sembelihan dengan tanpa melapalkan Basmallah masuk dalam kategori halal (Haq, 2006).

\section{KESIMPULAN}

Disimpulkan bahwa tidak dijumpai pelanggaran Animal Welfare pada proses penanganan ayam sebelum dan setelah pengangkutan, namun ada indikasi saat proses pencelupan ke dalam air panas setelah proses pemotongan. Penyembelihan ayam broiler di Kota Mataram masih belum mengikuti presdur baku yang ditetapkan oleh Direktorat Kesmavet dan Pasca Panen Dirjen Peternakan dan Kesehatan Hewan, Kementrian Pertanian Republik Indonesia, dan Badan Standarisasi Nasional Indonesia, namun sudah mengikuti prosedur baku yang ditetapkan oleh Majlis Ulama Indonesia, sehingga produk yang dihasilkan tergolong daging Halal. Perlu dilakukan pembinaan terhadap pengusahapengusaha yang bergerak dalam bidang pemotongan ayam broiler untuk mendapatkan daging yang ASUH.

\section{KONFLIK KEPENTINGAN}

Para penulis menyatakan tidak ada konflik kepentingan dalam artikel ini.

\section{UCAPAN TERIMA KASIH}

Terima kasih dan penghargaan yang tiada terhingga disampaikan kepada Universitas Mataram yang telah mendanai penelitian ini melalui surat kontrak perjanjian nomor 2865/UN18.L.1/PP/2020.

\section{DAFTAR PUSTAKA}

Ajakaiye, J.J., J.O. Ayo \& S.A. Ojo, 2010. Effects of heat stress on some blood parameters and egg production of Shica Brown layer chickens transported by road. Biol. Res. 43: 183-189.

Al-Aqil, A. \& I. Zulkifli, 2009. The changes in heat shock protein 70 expression and blood characteristics in transported broiler chickens as affected by housing and early age feed restriction. Poult. Sci. 88:1358-1364.

Al-Fataftah, A.A. \& Z.H.M. Abu-Dieyeh, 2007. Effect of chronic heat stress on broiler performance in Jordan. Int. J. Poult. Sci. 6 (1): 64-70

Al-Ghamdi, Z.H., 2008. Effects of commutative heat stress on immune responses in broiler chickens reared in closed system. Int. J. Poult. Sci. 7(10): 964-968.

Al-Mundziri Z.A. 2008. Ringkasan Shaheh Muslim. Diterjemahkan oleh: Syinqity Djamaluddin. Penerrbit Mizan. Bandung.

Ali Md. S, G.H. Kang \& S.T. Joo. 2008. A Review: Influences of Pre-slaughter Stress on Poultry Meat Quality. Asian-Aust. J. Anim. Sci. Vol. 21 (6): $912-916$.

Barbut, S., A.A. Sosnicki, S.M. Lonergan, T. Knapp \& D.C. Ciobanu et al., 2008. Progress in reducing the Pale, Soft and Exudative (PSE) problem in pork and poultry meat. Meat Sci., 79: 46-63.

BSN. 1999. Rumah Pemotongan Unggas. Badan Standarisasi Nasional Indonesia. SNI 01-61601999.

Consalesius, A.N., I.R.D. Annytha, \& A.W. Diana, 2014. Pengkajian Residu Tetrasiklin dalam Daging Ayam Pedaging, Ayam Kampung dan 
Penanganan Ayam Broiler Sebelum dan Sesudah Pemotongan: Studi Pengolahan Daging Broiler Di kota Mataram dan Sekitarnya (Tamzil dkk.)

Ayam Petelur Afkir yang Dijual di Kota Kupang. Jurnal Kajian Veteriner. 2(2):175-181.

Direktorat Kesmavet dan Pasca Panen. 2010. Pedoman Produksi dan Persyaratan Daging Unggas yang Higienis. Ditjen Peternakan dan Kesehatan Hewan. Jakarta.

Doktor J. \& K. Połtowicz, 2009. Effect of transport to the slaughterhouse on stress indicators and meat quality of broiler chickens. Ann. Anim. Sci. 9(3):307-317.

Etikaningrum \& S. Iwantoro. 2017. Kajian Residu Antibiotika pada Produk Ternak Unggas di Indonesia. Jurnal Ilmu Produksi dan Teknologi Hasil Peternakan. 5(1):29-33.

Ewing SA, Donald C, Lay Jr, \& Von Borrel E. 1999. Farm Animal Well-Being: Stress Physiology, Animal Behaviour, and Environmental Design. Printice Hall.

Haq, A. 2006. Formulasi Nalar Fikih: Kaidah Fikih Konseptual, Khalista.Surabaya.

Jayaprakash G,. M. Sathiyabarathi, M. Arokia Robert \& T. Tamilmani. 2016. Transportation Stress in Broiler Chicken. Internat. J. Sci. Environ and Technology. 5(2): $806-809$.

Lengkey, H.A.W., J. A., Siwi1, P. Edianingsih, \& J. Nangoy. 2013. The Effect of Transportation on Broiler Meat $\mathrm{pH}$ and Tenderness. Biotec. Anim. Husban. 29 (2):331-336.

Lin H., H.F. Zhang, R. Du, X.H. Gu, Z.Y. Zhang, J. Buyse, \& E. Decupere. 2005. Thermoregulation responses of broiler chickens to humidity at different ambient temperatures. II. Four weeks of age. Poult Sci 84:1173-1178.

MUI. 2009. Standar Sertifikasi Penyembelihan Halal. Fatwa Majelis Ulama Indonesia Nomor 12 Tahun 2009 Tentang Standar Sertifikasi Penyembelihan Halal.

Moberg G.P., 2000. Biological response to stress: Implications for animal welfare. In: G. P. Moberg and J. A. Mench (ed). The Biology of Animal Stress. CABI Publishing, UK. Pp 1-21.
Trivedi K \& Bhargava, 2010. Relation of creativity and educational achievemen in adolelescence. J. Psychology. 1(12):85-89.

Tamzil M.H., 2014. Stres Panas pada Unggas: Metabolisme, Akibat dan Upaya Penanggulangannya. Wartazoa. 24(20):57-67.

Tamzil M.H., B. Indarsih \& I.N.S. Jaya . 2019. Rest Before Slaughtering Alleviates Transportation Stress and Improves Meat Quality in Broiler Chickens. Int. J. Poult. Sci., 18 (12): 585-590.

Tamzil, M.H., B. Indarsih \& I.N.S. Jaya, 2018. Water Spraying Prior to Transportation Reduces Transportation Stress and Maintain the Meat Quality of Broiler Chickens. Pak. J. Nutr. 17 (11): 550-556.

Tamzil M.H., N.K.D. Haryani \& B. Indarsih, 2016, Reduced Expression of Heat Shock Protein (HSP) 70 Gene by Ascorbic Acid Supplementation in Broiler Chickens Exposed to Transportation Stress to Maintain the Quality of Meat and Hematological Parameters. Int. J. Poult, Sci., 15 (11): 432-441.

Yulianti, N.T., N. Ariyani, Nurhidayah, \& E. Nugraha. 2016. Kajian Residu Antibiotik Golongan Tetrasiklin dan Penisilin dalam Daging, Hati, Usus dan Paru-paru Ayam Broiler di 13 Provinsi di Indonesia. Buletin Pengujian Mutu Obat Hewan No.25.

Zhang L, H.Y. Yue,, H.J. Zhang, S. G. Wu, H.J. Yan , YS. Gong, \& G.H. Qi. 2009. Transport stress in broilers: I. Blood metabolism, glycolytic potential, and meat quality. Poult Sci. 88(10):2033-41

Zulkifli, I., A. Al Aqil, A.R. Omar, A.Q. Sazili \& A. Rajion, 2009. Crating and heat stress influence blood parameters and heat shock protein 70 expression in broiler chickens showing short or long tonic immobility reactions. Poult. Sci. 88:471-476. 